\title{
The silent narrative you may have missed in Jedda
}

\author{
Kellie Dillon \\ University of Technology Sydney, Faculty of Arts and Social Sciences, PO Box 123, Ultimo NSW \\ 2017, Australia.kellie.dillon@student.uts.edu.au
}

DOI: https://doi.org/10.5130/nesais.v4i1.1523

Jedda, directed by Charles Chauvel and written by his wife Elsa Chauvel, was a landmark film for Australian cinema because of its groundbreaking firsts: it was the first film to cast Indigenous actors in lead roles, the first to be shot in colour, and the first Australian film to compete in the Cannes Film Festival. Jedda is largely of Australian historical interest as it offers an insight into race relations of the 1950s, ideas of Aboriginal assimilation, and inadvertently, the Stolen Generations.

Jedda is set on a buffalo station in the Northern Territory that is run by Sarah and Douglas McMann. Following the death of her own baby, Sarah McMann informally 'adopts' an orphaned Aboriginal baby girl whose mother died at birth. The baby's father is Bulu, an Aboriginal drover who works for Douglas McMann. Bulu brings the baby to the station in the hopes one of the Aboriginal women on the station will take her. The baby was named Jedda, meaning 'little wild goose', by the group of Aboriginal women. After being reluctant to take her in at first, Sarah warms up to Jedda and raises her as her own daughter.

The first part of the film deals with Jedda's childhood and development into a young woman. Sarah and Douglas McMann have heated discussions on whether a 'full-blooded' Aboriginal such as Jedda can be successfully assimilated into white society. "It's our duty to do something with them, bring them closer to our way of living," argues Sarah, while Douglas maintains, "You won't wipe out the tribal instincts and desires of a thousand years in one small life." In a particularly powerful scene, Sarah McMann is rolling out dough in the kitchen while trying to teach Jedda the alphabet. Jedda makes animal tracks with her fingers in the dough, which she learned from other Aboriginal children on the station. The voiceover narrates, "It was a tough job trying to teach Jedda the A-B-C of the white child and capture a mind constantly out in the world of her dark people." Sarah disciplines Jedda and uses her rolling pin to erase all traces of Aboriginality on the dough. Anthropologist Jeremy Beckett has described Jedda's actions in this scene as 'a disturbance' to Sarah McMann's 'pedagogical regime' of assimilation (Beckett 2000, p. 98).

As Jedda grows into a young woman, she yearns to be a part of her culture and join the other Aboriginal people on walkabout, to which Sarah McMann responds "Jedda, whatever would you do out in the bush with all those naked monkeys? I have other plans for you Jedda, I want you to go on 
living like a white girl, like my own daughter." The negative representations and stereotypes of Aboriginal people in Jedda are reflective of the reality of policy-making at the time. The 1950s in Australia saw assimilation policies equate to the social typing of Aboriginal people, who were believed to be an inferior, primitive race and better off either being assimilated completely or destroyed.

Sarah McMann is a significant character in Jedda, not only for her embodiment of the assimilationist attitudes of the time, but also as she becomes a figure of "colonial domesticity, through which normative performances of gender also underline normalised racial hierarchies" (Lloyd 2014, p. 1052). The film's set design 'miniaturises' the vastness of the Australian landscape, thereby domesticating it. Lloyd suggests the "domestication of landscape in the film clearly relates to the practices of colonisation. Figures of pioneer and rural women provide modes of moral instruction strongly associated with colonial settlement, assimilation and racial purity. Their domestic labour enables the colonial project, and gives the settlement process its shape and meaning at a time when homemaking was synonymous with nation-building. The 1950 s were a high point of a colonising domesticity for Indigenous people" (Lloyd 2014 p. 1051).

Critical writings concerning Jedda tend to focus on Sarah and Douglas McMann's opposing views of assimilation. Although the film's central themes of assimilation and "the predicament of the Aboriginal people living under the paternalistic control of a dominant white culture" (Creed 2013, p. 209) are extremely significant, the story of Jedda cannot be separated from a narrative of the Stolen Generations. Creed suggests:

This 'silent' narrative, repressed by the very staged debates between Sarah and Doug, concern Jedda's origins and arrival at the homestead. She is, in effect, one of the children of the stolen generations. Her tale of 'captivity', represented in the film not as captivity but as a tale of Jedda's good fortune, occupies the first half of the narrative, where the drama is played out in and around the McMann homestead. (Creed 2013, p. 210)

In the scenes where Sarah first encountered baby Jedda, she was reluctant to take her in due to her still raw grief of the loss of her own baby. At no point in any of these scenes were there suggestions to place Jedda in the care of her own people. This is an important aspect of the film to note, as it points to the paternalistic control of white people over Aboriginal children and the attitudes towards removal of Aboriginal children from their communities.

Re-watching Jedda sparks the question: is it morally justifiable for white people such as Chauvel to tell Indigenous stories? It is my assertion that, although limited by the racial discourse of the time, Jedda is an important starting place to observe how far Indigenous people have come in the film industry. Today, Indigenous people can finally tell their own stories, such as Tracey Moffatt, whose 1990 short film Night Cries is often seen as a response to Jedda. Jedda is a powerful film in Australian history, and looking back at it from a liberal lens offers many confronting truths about the harsh realities Aboriginal people have faced and continue to face since invasion. 


\section{References}

Beckett, J. 2000, 'Sarah McMann's Mistake: Charles Chauvel's Jedda and the Assimilation Policy', In Picturing the Primitif: Images of Race in Daily Life, edited by Julie Marcus, pp. 91-103.

Creed, B. 2013, 'Breeding out the black: Jedda and the Stolen Generations of Australia', Body Trade: Captivity, Cannibalism and Colonialism in the Pacific, Routledge, Florence. pp.208-230. https://doi.org/10.4324/9781315023823

Lloyd, J. 2014, 'Domestic destinies: colonial spatialities, Australian film and feminist cultural memory work', Gender, Place \& Culture, 21:8, pp.1045-1061.

https://doi.org/10.1080/0966369X.2013.810606 